\title{
Functional impairment and killing of human beta cells by enteroviruses: the capacity is shared by a wide range of serotypes, but the extent is a characteristic of individual virus strains
}

\author{
M. Roivainen ${ }^{1}$, P. Ylipaasto ${ }^{1}$, C. Savolainen ${ }^{1}$, J. Galama ${ }^{2}$, T. Hovi ${ }^{1}$, T. Otonkoski ${ }^{3}$ \\ ${ }^{1}$ Enterovirus Laboratory, National Public Health Institute, Helsinki, Finland \\ 2 Department of Medical Microbiology, University Medical Center Nijmegen, Nijmegen, The Netherlands \\ 3 Transplantation Laboratory, Haartman Institute, and Children's Hospital, University of Helsinki, Helsinki, Finland
}

\begin{abstract}
Aims/hypothesis. Direct infection of beta cells could explain the diabetogenic effect of enteroviruses. Primary adult human beta cells are susceptible to coxsackievirus infections, which could result in impaired beta-cell function or cell death (coxsackieviruses B3, B4, B5) or both, or no apparent immediate adverse effects (coxsackievirus A9). We extended these studies to additional enterovirus serotypes including several echoviruses, some of which have been associated clinically with the development of Type I (insulin-dependent) diabetes mellitus.

Methods. The patterns and consequences of enterovirus infections were investigated in cultured adult human isolated islets. Cell type-specific infection and viability were assessed by immunocytochemical meth-

cant functional impairment $(p<0.05)$ and beta-cell death. In contrast, echovirus serotypes 9 and 30 were not destructive. However, when several different field isolates of echovirus 30 were investigated, some of them were found to be clearly more destructive than the corresponding prototype strain. This was also true for echovirus 9. A strain isolated from a 6-week-old baby suffering from acute Type I diabetes was functionally more destructive than either of the echovirus 9 prototype strains.

Conclusion/interpretation. These observations indicate that the capacity of an enterovirus to kill human beta cells or impair their function is not entirely defined by the serotype, but in addition by as yet unidentified characteristics of the virus strain involved. Moreover, any serotype could potentially be diabetogenic. [Diabetologia (2002) 45:693-702]
\end{abstract} ods. Beta-cell function was studied by perifusion.

Results. Poliovirus type 1/Mahoney, coxsackievirus A13, human parechovirus 1 and several echoviruses (serotypes $6,7,11$ ) were capable of causing signifi-

Keywords Enterovirus, coxsackievirus, echovirus, prototype strains, field isolates, cytopathic effect, primary pancreatic beta-cell, insulin release.

Received: 17 October 2001 / Revised: 16 January 2002

Published online: 6 April 2002

(C) Springer-Verlag 2002

Corresponding author: M. Roivainen, Enterovirus Laboratory, National Public Health Institute, Helsinki, Finland, E-mail: merja.roivainen@ktl.fi

Abbreviations: A-549, Human lung carcinoma cell line; BGM, Buffalo Green Monkey cells; CBV, coxsackievirus B; CBV-4E2, diabetogenic strain E2 of CBV-4; CAV, coxsackie A virus; EV, echovirus; GMK, green monkey kidney cell line; HPEV-1, human parechovirus 1; HSP-60, heat shock protein 60; IA-2, tyrosine phosphatase; M.O.I., multiplicity of infection; NCS, normal calf serum TCID $_{50}$ median tissue culture infectious dose

Type I (insulin-dependent) diabetes mellitus is a chronic disease of insulin deficiency resulting from gradual destruction of the insulin-producing pancreatic beta cells. Beta-cell loss is considered to result from a multifactorial process, involving host genes, autoimmune responses, cytokines and environmental factors. The process often starts years before clinical symptoms become manifest. Several lines of evidence suggest a role for enteroviruses as inducers or accelerators of the pathogenetic process $[1,2,3,4,5,6,7,8$, $9,10]$. During infection enteroviruses could reach the pancreatic islets and destroy insulin-producing beta cells by virus-induced cytolysis. Alternatively, betacell damage could result from a virus-induced inflam- 
matory reaction $[11,12]$. Furthermore, beta-cell destruction might be based on molecular mimicry, because immunological cross-reactions between enterovirus proteins and beta-cell autoantigens (GAD-65, HSP-60, IA-2) have been documented at least in vitro ([13, 14, 15], Härkönen et al., in press). The GAD-65 mimicry motif PEVKEK has been demonstrated to bind the diabetes risk allele DR 3 [16].

Enterovirus serotypes associated with the pathogenesis of Type I diabetes have been assessed by cross-sectional and prospective studies on Type I diabetes patients or prediabetic individuals or both. The results suggest that several out of the 64 human enterovirus serotypes should be considered potentially diabetogenic $[1,17]$. Observational studies revealing post-enterovirus-epidemic peak incidences of Type I diabetes [18, 19] and case reports [20,21] support this view. It is possible that the relative extent of diabetogenicity can vary within a serotype as genetic variation between field strains of a given enterovirus serotype is extensive.

Assuming that infection of cultured beta cells is relevant to the diabetogenic effect of enterovirus infection, we monitored patterns and consequences of enterovirus infections in primary adult human insulinproducing beta cells. Our previous results have shown that primary human beta cells are susceptible to infections by prototype strains of several coxsackie viruses $(\mathrm{CV})$ and that the infection could result in either impaired beta-cell function or beta-cell death (CBV-3, CBV-4 and CBV-5) or both, or has no apparent immediate adverse effects, as shown for CAV-9 [22]. Susceptibility of primary human beta cells to CBV-3, 4 and 5 have also been shown in some other studies [21, $23,24,25]$. In our study, we assessed diabetogenic properties of different enteroviruses including several serotypes of echoviruses. Importantly, several field isolates were studied in addition to the prototype strains.

\section{Materials and methods}

Human beta cells. Human pancreatic islets were isolated and purified in Brussels at the Central Unit of the Beta-Cell Transplant (coordinator D. Pipeleers) and sent to Helsinki as freefloating islets after 3-15 days of culture in Ham's F10 medium supplemented with $10 \mathrm{mmol} / \mathrm{l}$ HEPES $\mathrm{pH} 7.35+2 \%$ normal calf serum). The mean proportion of beta cells in the human islet preparations was $56 \pm 12 \%$ (means $\pm \mathrm{SD}, n=43$ ). Before experiments started, the suspended islets were maintained in sterile non-adherent culture plates in serum-free incubation medium (Ham's F10 containing $1 \%$ bovine serum albumin, $25 \mathrm{mmol} / \mathrm{l} \mathrm{HEPES}, \mathrm{pH}$ 7.4, penicillin and streptomycin).

Viruses. Prototype strains of coxsackie B viruses (CBV-1-6), echoviruses (EV-1, 6,7, 9,11,30), some coxsackie A viruses (CAV-9/Griggs and CAV-13), human parechovirus 1 (HPEV-1, previously known as echovirus 22) and poliovirus type 1/ Mahoney were obtained either from the American Type Culture
Collection or from World Health Organization Enterovirus reference laboratory (Copenhagen, Denmark). The diabetes-associated strain CBV-4-E2 was kindly provided by Dr J.-W. Yoon [1]. Viruses were passaged in continuous cell lines of monkey kidney origin (GMK) or human lung carcinoma (A-549). The serotype of all virus preparations used was confirmed by using a neutralisation assay with type-specific antisera.

Field isolates. Seven isolates of EV-30 collected from Finland, The Netherlands, Israel, France and Lithuania between 1975-1998 were included in this study after passaging in RD cells [26]. Partial sequences of the strains have been determined and deposited in GenBank with accession numbers AF236519, AF236521, AF236538, AF236545, AF236550, AF236574. They represented three different subgenotypic lineages of the single prevailing genotype of EV-30 in Europe between 1977 and 1998 [26]. Special care was taken to avoid changes due to multiple passaging of the viruses. All the seeds used were of low passage virus. First local passages prepared from them were stored frozen as small aliquots. Working stocks were prepared by infecting suitable cells with the first passage virus and again, dividing in small aliquots.

The echovirus 9 DM strain was the stool isolate from a 6-week-old baby suffering from acute Type I diabetes. The strain was isolated in tertiary monkey kidney cell [21] and passaged twice in Buffalo Green Monkey cells before use in the present experiments. The serotypes of all isolates were confirmed by using serotype-specific neutralising antiserum.

Replication of viruses. Free-floating islets were infected with apparent high multiplicity (M.O.I. 30-100) of different virus preparations. After adsorption for one hour at $+36^{\circ} \mathrm{C}$ the inoculum virus was removed, the cells were washed twice with Hanks balanced salt solution supplemented with $20 \mathrm{mmol} / \mathrm{l}$ Hepes, pH 7.4 and serum free incubation medium was added to all cultures including uninfected controls. Infected and uninfected islets were divided into aliquots on 96 well (virus titration, IF and viability stainings) or 24-well (perifusion, insulin and DNA) tissue culture plates and incubated at $36^{\circ} \mathrm{C}$. During the experiment the incubation medium was changed twice a week, the first change at two days after infection.

For virus titration samples of suspended islets harvested at 0,1 and 2 days after infection were frozen and thawed three times to release the virus, clarified by low-speed centrifugation and assayed for total infectivity by using end-point dilutions in microwell cultures of GMK cells (HPEV-1 in A-549 cells). Cytopathic effects were read on day 6 by microscopy and tissue culture infections dose $\left(\mathrm{TCID}_{50}\right)$ titres were calculated as described earlier [22].

Immunocytochemistry. Samples of infected and uninfected islets were harvested at one day after infection on glass slides using a cytocentrifuge and fixed with cold methanol for $15 \mathrm{~min}$ at $-20^{\circ} \mathrm{C}$. After washings (three times with PBS) they were double-stained for $1 \mathrm{~h}$ at $36^{\circ} \mathrm{C}$ with enterovirus-specific polyclonal rabbit antiserum (1:400, KTL-910, ref. [27]) or with HPEV-1-virus-specific polyclonal rabbit antiserum (used at a dilution of 1:400) and insulin-specific polyclonal sheep antiserum (1:200; PH059, The Binding Site, Birmingham, England). Visualization was achieved by FITC (711-095-152, Jackson ImmunoResearch, Penn., USA) and red X (713-295-147, Jackson ImmunoResearch) conjugated anti-species sera and analysed using a confocal microscope Leica TCS NT (Wetzlar, Germany).

DNA and insulin content of cells. For the measurement of DNA and insulin content, islet cells were homogenized ultra- 
sonically in distilled water. DNA was measured from dried samples fluorometrically based on diaminobenzoic acidinduced fluorescence [28]. Insulin was measured with a commercial solid-phase insulin RIA kit (DPC, Los Angeles, Calif., USA) after overnight extraction with acid ethanol as described previously [29].

Cell viability. Viability of islet cells after infection was measured using a commercial kit (the live / dead cell assay, L-3224, Molecular Probes, Leiden, The Netherlands). The assay is based on the simultaneous determination of live and dead cells with two fluorescent probes. Live cells are stained green by calcein due to their esterase activity while the nuclei of dead cells are stained red by ethidium homodimer-1. Islets harvested at different time points were incubated with the labelling solution for $30 \mathrm{~min}$ at room temperature in the dark, cytocentrifuged onto glass slides and analysed with a confocal microscope Leica TCS NT (Wetzlar, Germany).

Beta-cell function. Insulin secretion in response to glucose and glucose plus theophylline was studied by perifusion as described previously [22, 30]. Briefly, after taking samples for insulin content and DNA measurement, islets were loaded in perifusion chambers in Krebs-Ringer bicarbonate buffer supplemented with $20 \mathrm{mmol} / \mathrm{l}$ Hepes (pH 7.35) and 0.2\% BSA. After a $60 \mathrm{~min}$ stabilizing period in low glucose $(1.67 \mathrm{mmol} / \mathrm{l})$, the cells were stimulated first with a $16.7 \mathrm{mmol} / \mathrm{l}$ glucose and then with a mixture of $16.7 \mathrm{mmol} / \mathrm{l}$ glucose and $10 \mathrm{mmol} / \mathrm{l}$ theophylline (Sigma, St. Louis, Mo., USA). Fractions of $1 \mathrm{ml}$ were collected every $4 \mathrm{~min}$ and analysed for insulin by RIA. After stimulations the basal buffer $(1.67 \mathrm{mmol} / \mathrm{l}$ glucose $)$ was used during the final 2 fractions. Up to six perifusion lines were run in parallel using a multi-channel perifusion apparatus (Brandel, Gaithersburtz, Md., USA).

Statistical methods. Because of a considerable variation between experiments with islets from different donors, the results were analysed as relative changes normalized against the uninfected control islets from each donor (standardized control mean $=1.0$ ). Differences between groups were tested with Statview 4.1 software for the Macintosh (Abacus Concepts, Berkeley, Calif., USA). If this indicated that the groups differed significantly from each other ( $p$ value for the $\mathrm{F}$ parameter $<0.05$ ), - the individual significances of each virus were tested with the one-sample $t$ test against the hypothesized mean of 1.0.

\section{Results}

Replication of prototype strains of enterovirus serotypes in adult human beta cells. All tested enteroviruses, including prototype strains of CBV-1,2,6, CAV-13, EV-1,6,7,9,11,30, PV-1 and HPEV-1 regularly replicated in primary human islets and the maximum amount of progeny virus was yielded rapidly, always at one or two days after infection (Fig. 1). Each experiment meant a different donor and with some viruses donor-related differences were clearly seen. Echovirus-30 was not able to replicate in one out of four experiments.

Infection of insulin-producing beta cells at one day after infection was documented by a dual label immunofluorescence resulting in red fluorescent insulinproducing beta cells and green fluorescent virus-
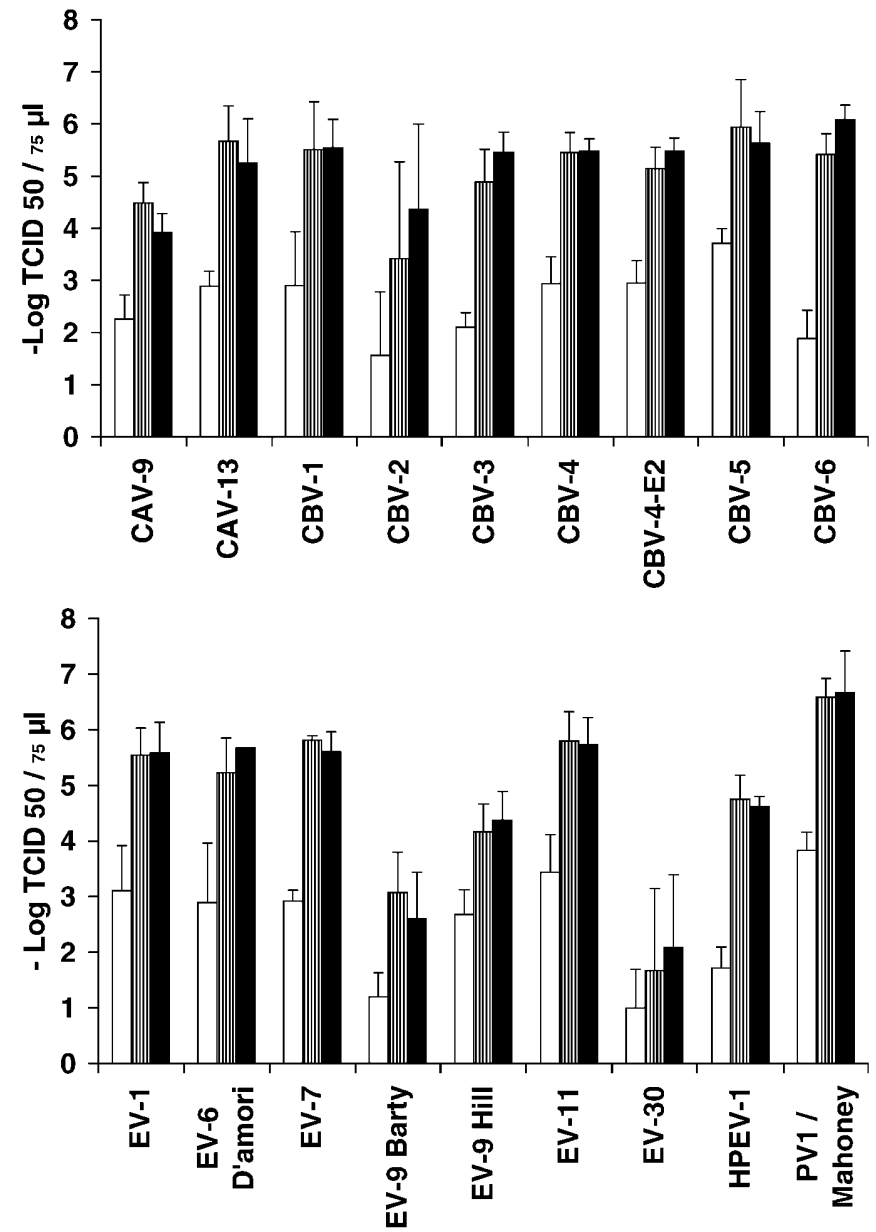

Fig. 1. Replication of enteroviruses in primary adult human islets. Parallel aliquots of islets were infected with apparent high multiplicity (30-100 plaque-forming units/cell) of different enteroviruses. After $1 \mathrm{~h}$ adsorption period the inoculum virus was removed, islets were washed twice, and culture medium was added. Samples taken at different intervals were assayed for total infectivity and results are shown as the mean $\pm 95 \%$ CI. Left column, 0 h; middle column, 1 day; right column, 2 days

infected cells. Yellow and orange double fluorescence was seen after most infections (Fig. 2) indicating that the virus was capable of infecting insulin-producing beta cells. Echovirus 1 was the only one of the tested viruses not showing obvious yellow and orange fluorescence. This suggests that this virus, at least initially, mainly infected other cell types than beta cells. At 2 days of infection, yellow fluorescence was clearly evident in EV-1-infected islets as well (not shown). Interestingly, in the case of some echoviruses, like EV-9 and EV-30, only yellow fluorescence was seen (Fig. 2), indicating that these viruses preferentially infected the insulin-producing beta cells.

Consequences of enterovirus infection in adult human beta cells. Through all our experiments uninfected control islets remained viable and only few solitary dead cells were seen around them occasionally (Fig. 3). At 3-4 days after infection, the majority of 


\section{Control}

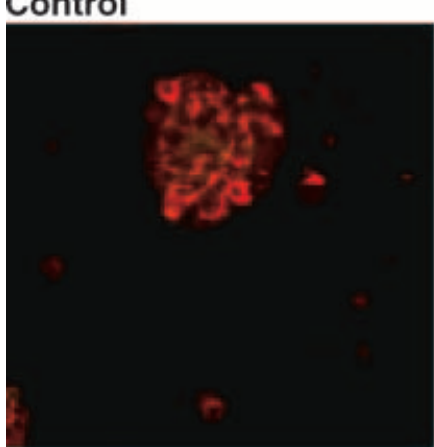

EV-9/Barty

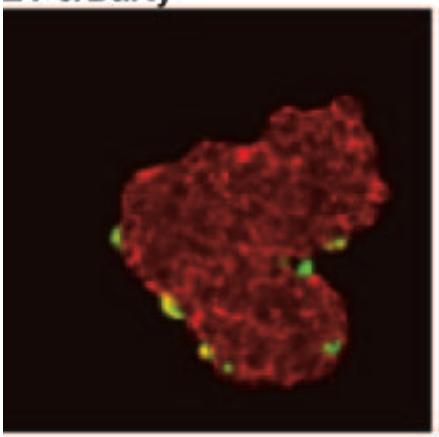

CAV-13

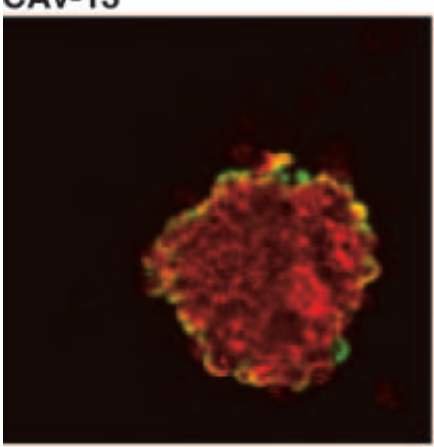

\section{Control}

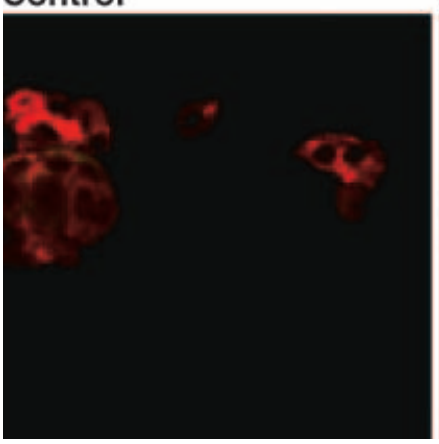

EV-1

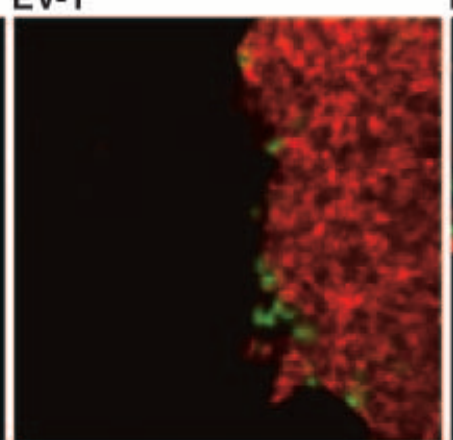

EV-9/Hill

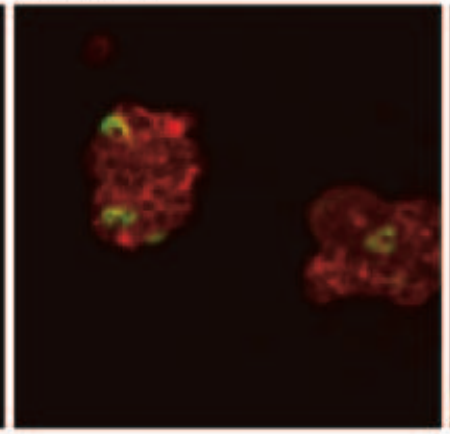

CBV-1

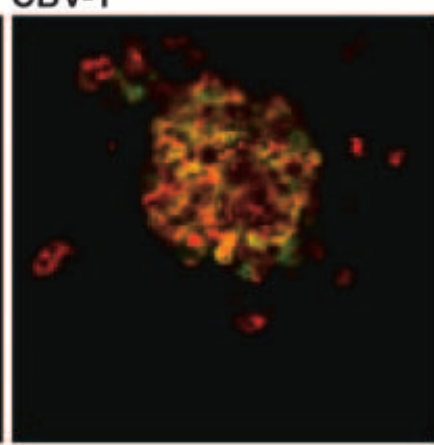

HPEV-1

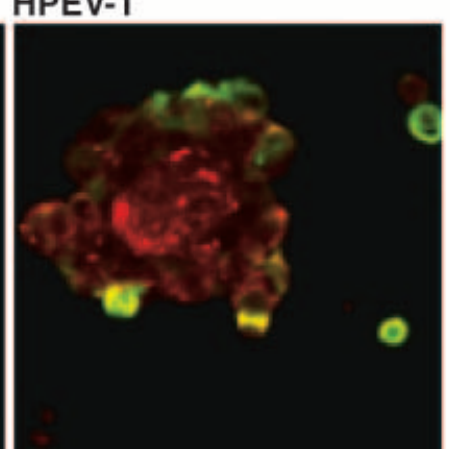

EV-6

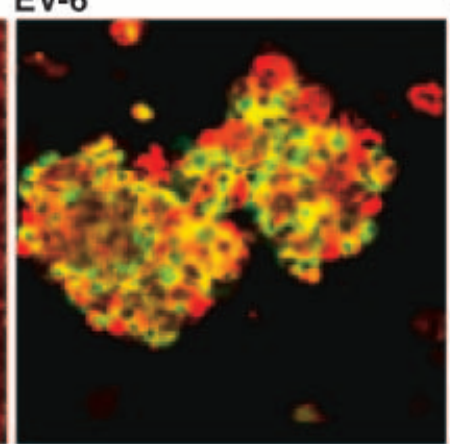

EV-7

\section{EV-11}

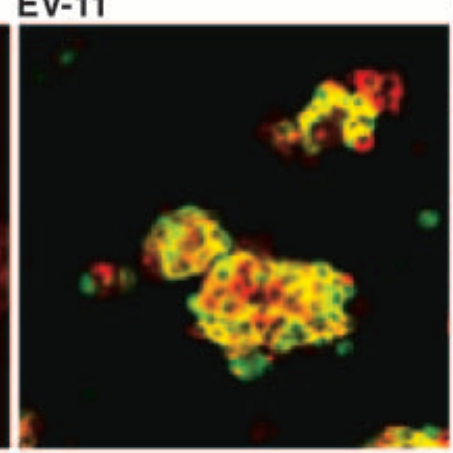

EV-30

CBV-6

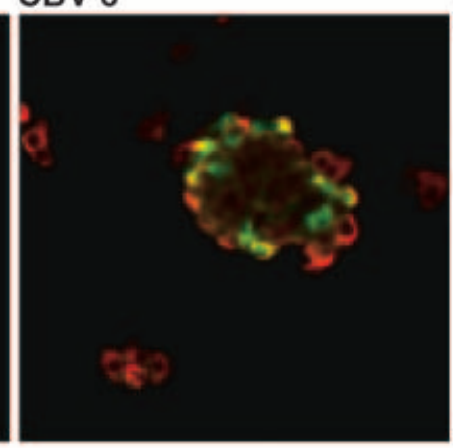

PV-1/Mahoney

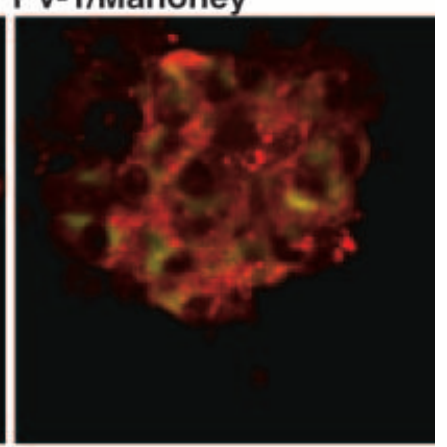

Fig. 2. Enterovirus infection in insulin-producing beta cells. Uninfected control islet and virus-infected islets were harvested 1 day after infection. Cytocentrifuged spots of harvested cells were fixed with cold methanol and double stained with enterovirus-specific rabbit antiserum and insulin-specific sheep antiserum. Visualization was performed by FITC-antirabbit (green, for virus antigen) and redX-antisheep (red, for insulin) conjugates. Infected insulin-producing cells can be recognized by their yellow colour

the islets infected with CBV-1 were dead indicating that this virus is highly cytolytic. The same result was obtained with CBV-6, CAV-13, PV-1 (not shown) and has been previously reported for CVB-3,4 and 5 [22]. In contrast, echoviruses 6,7, and 11 (Fig. 3) and CBV-2 (not shown) were not able to kill all islet cells within this time span, as some small viable islets remained in cultures infected with these viruses. Although islets infected with echovirus 9, strain Barty or Hill, often looked intact at 3-4 days after infection, a number of dead cells were found around them (Fig. 3). These dead cells were mostly insulin positive as documented by IF-staining with insulin-specific antiserum (not shown). Cultures infected with EV-30 (Fig. 3), EV-1 (not shown) and CAV-9 [22] did not show any virusinduced adverse effects within 3-4 days. 
CONTROL

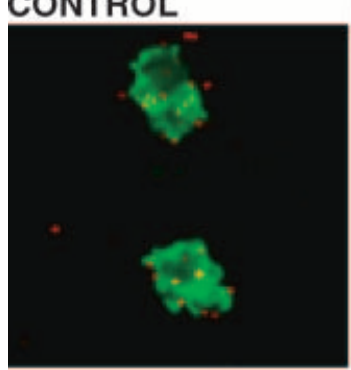

EV-6

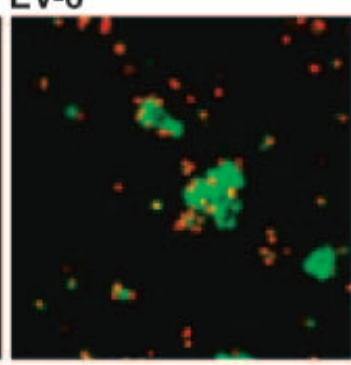

CONTROL

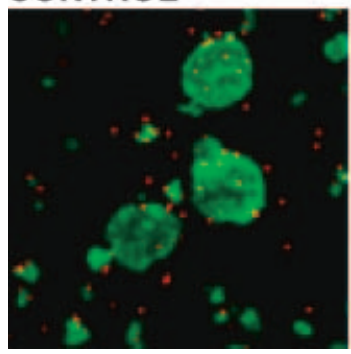

CBV-1

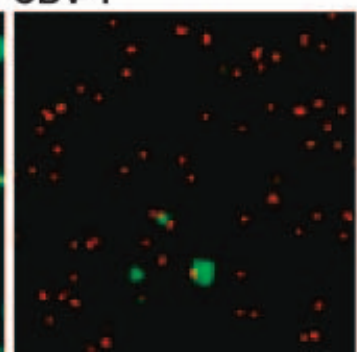

Fig. 3. Effect of enterovirus infection on human islet-cell viability. Infected and uninfected control islets were harvested at 3-4 days after infection and stained with the live/dead cell assay kit. Live cells are stained green by calcein due to their esterase activity, whereas red fluorescence is induced in the nuclei of dead cells by ethidium homodimer-1. For each virus results from one typical experiment are shown

Insulin secretion by viable human beta cells is known to respond well to secretagogues in vitro. In our hands, responses of uninfected control islets were practically unchanged even 26 days after isolation (not shown). At one week, uninfected human beta cells responded to glucose with a biphasic pattern of insulin release with a 4.1-fold increase in the first phase peak followed by a prolonged second phase (3.4-fold over the basal concentration) (Fig. 4A). Finally the glucose response was further potentiated by theophylline, a phosphodiesterase inhibitor exerting its effect through an acute increase of the intracellular cAMP concentration (9.5-fold increase in insulin concentrations over the basal concentration). Stimulation indices were calculated separately for the first-phase and second-phase glucose responses and for the response obtained by glucose and theophylline. Effects of various enterovirus infections on these parameters are shown in Figure 4. All stimulated responses were drastically impaired by infections with EV-7, 11, CAV-13, CBV-5, 6 and PV-1 (Fig. 4B, C, D). The susceptibility of beta cells to some viruses was more variable. After infections by CBV-1, 3,4 and HPEV-1 two out of three stimulated responses (the first-phase or the second-phase response to glucose and response to glucose plus theophylline) were decreased, while infections caused by CBV-4E2 and EV-6 induced a detectable defect only in one of the measured responses (Fig. 4B, C, D). Islets infected with CBV-2 and EV-30 usually responded like uninfected controls. A clearly
EV-11

EV-30
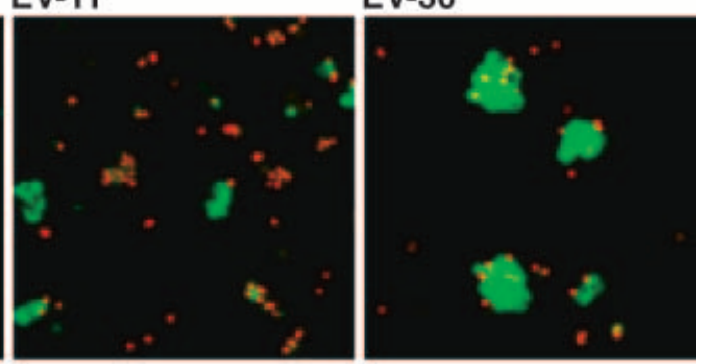

EV-9 HILL

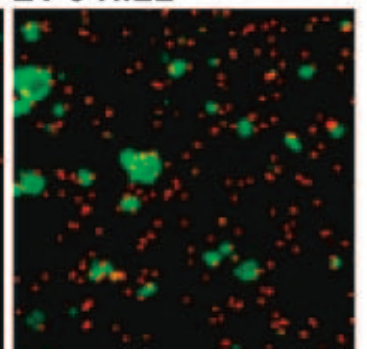

exaggerated insulin response was often seen in islets infected with EV-9/Barty and CAV-9 (Fig. 4B, C, D).

Figure 4E illustrates the effect of enterovirus infections on islet insulin content per total cellular DNA. This parameter reflects the selective destruction of beta cells, although infection-induced suppression of insulin synthesis could also affect the ratio. The insulin content was significantly reduced $(p<0.05)$ by infections with $\mathrm{CBV}-1,3,4 \mathrm{E} 2,5,6, \mathrm{EV}-6,7,11, \mathrm{PV}-1$ and HPEV-1. The most consistent destruction of islets from different donors was evident for CBV-1 and 3, and EV-7 (Fig. 4E). Even after infection with the most deleterious virus some individual beta cells survived at one week after infection. In general, the insulin for each DNA ratio correlated well with the insulin secretion results obtained in perifusion experiments. The only virus causing impairment in insulin release without significantly affecting insulin content was CAV-13.

Are serotypes EV-9 and EV-30 less diabetogenic than other enteroviruses? Prototype strains of EV-9 and 30 were often non-destructive in beta cells. In order to find out whether this property is conserved among these serotypes, beta cell tropism of several field isolates was studied. Results obtained with islets from two different donors infected with EV-9 DM isolated from a 6-week-old baby at the onset of acute Type I diabetes are shown in Figure 5. Prototype strains of EV-9 (Hill and Barty) were studied in parallel in the same islets preparations. Although some donor-related variation was seen in virus susceptibility between different preparations, the recent isolate replicated well in both islet preparations and caused more beta-cell destruction than the prototype strains.

Seven field isolates of EV-30 were taken for studies of beta-cell tropism. Replication of isolates in an islet preparation from one donor are shown in Figure 6A. Selective destruction of beta cells by EV-30 isolates 

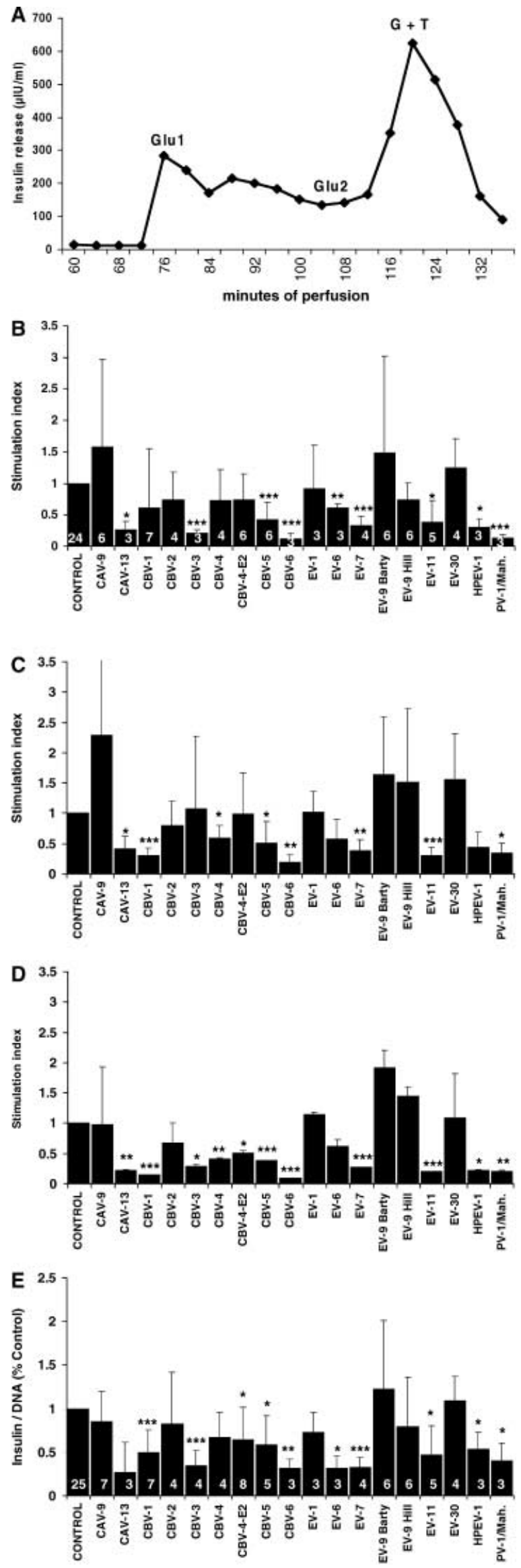

was studied by measurement of intracellular insulin content. As shown in Figure 6B strains isolated in The Netherlands 1977, 1979, 1987 and France 1996 were clearly more destructive than the other isolates and the corresponding prototype strain, Bastianni. Similar results were obtained with another islet-cell preparation (not shown).

\section{Discussion}

In this study, we have shown that primary adult human insulin-producing beta cells are susceptible to infections caused by several prototype strains of enteroviruses, representing different genetic subgroups (PV, HEV-B and C) and acting through different receptor families. According to our results all tested enterovirus serotypes did grow in the islets cells but the outcome of infection was highly variable. Enterovirus serotypes were easily divided in two categories: cytolytic viruses resembling the prototype strains of CBV-4 and 5 in our previous study; and viruses without apparent cytolytic effects, resembling the effect of CAV-9 [22]. Enterovirus serotypes capable of causing cytolysis and functional impairment at one week after infection were echovirus 6,7,11 CAV-13, CBV-1, 3, 4, $5,6, \mathrm{PV}-1$ and HPEV-1. Variation between virus-induced effects on beta cells was not entirely serotype defined. Interestingly, field isolates of benign serotypes were found to be highly cytolytic in beta cells suggesting that diabetogenicity is not stably associated with serotypes, but with individual isolates. Donorrelated variation in islet-cell susceptibility to infections was evident in some viruses. It is not known why the beta cells of some donors are better protected against enterovirus infections. However, donor-specific factors, such as cytokine response capability, infection history and HLA-types could be important.

EV-30, CBV-2, EV-1 and 9 were less destructive, without an immediate adverse effect on stimulated in-

Fig. 4A-E. Effect of enterovirus infection on intracellular insulin content and stimulated insulin release at one week after infection. A Stimulated release of insulin in uninfected human beta cells in perifusion experiments. Response of beta cells to high glucose (Glu 1 and Glu 2) and to a mixture of high glucose and theophylline $(\mathrm{G}+\mathrm{T})$. Stimulated insulin release is shown as $\mu \mathrm{IU} / \mathrm{ml}$. One representative experiment. B-D Cumulative effect of enterovirus infection on stimulated release of insulin. Insulin release, expressed as the stimulation indices (stimulated/basal concentration) in response to high glucose and theophylline are shown as relative changes from the uninfected control (B, Glu 1; C, Glu 2, D, G+T). E Insulin content per cellular DNA of the uninfected and infected islets, expressed as relative changes from the uninfected control. The number of observations is indicated at the bottom of the columns. The mean \pm standard deviation is shown in the panels. Significance of impaired response $* p<0.05 ; * * p<0.01$, $* * * p<0.005$ (compared with the uninfected control cells) 

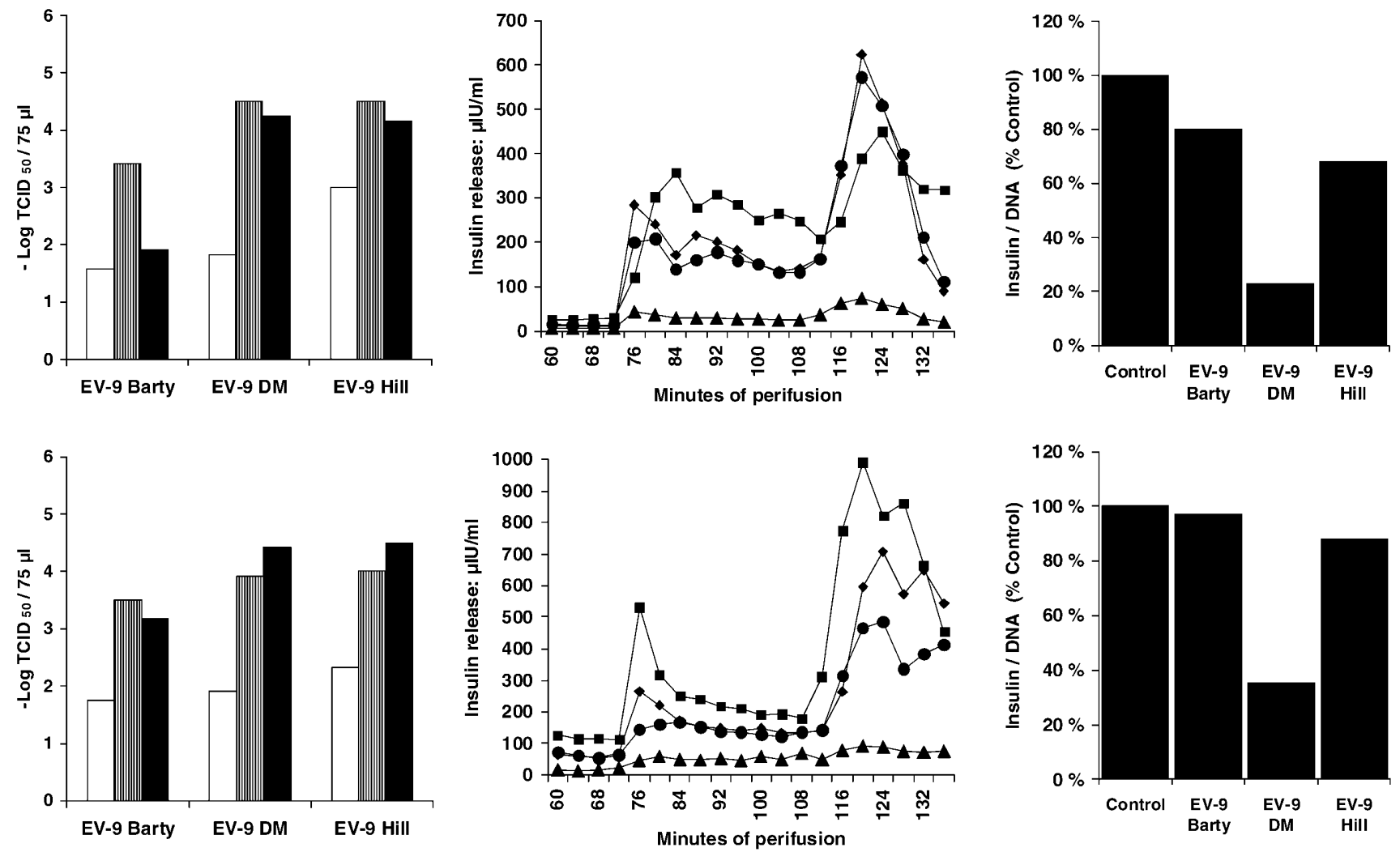

Fig. 5. Beta-cell destruction caused by the recent field isolate, EV-9 DM. Two different sets of islets were infected with prototype strains of EV-9, Barty or Hill, or the field isolate EV-9DM. Effect of virus infections on insulin secretion are shown in the middle panels (- - Control, $-\square-$ EV-9 Barty, - $\mathbf{\Delta}$ - EV-9 DM, - - EV-9 Hill) (stimulated insulin release is shown as $\mu \mathrm{IU} / \mathrm{ml}$ along $\mathrm{y}$-axis and minutes of perifusion along $\mathrm{x}$-axis), intracellular insulin content in right-hand panels and virus replication in left-hand panels (left column, $0 \mathrm{~h}$; middle column, 1 day; right column, 2 days)

sulin release. However, in the case of EV-9, a clear virus-induced cytolysis was evident in a subpopulation of beta cells. Interestingly, this was true for both strains of EV-9, Hill and Barty, although they are known to have different receptor specificity in continuous laboratory cell lines and newborn mice [31]. Interestingly, EV-9 and EV-30 infected almost solely insulin-producing beta cells, while another echovirus, EV-1, appeared to initially target non-beta cells. We do not know whether this kind of beta-cell tropism is characteristic for a diabetogenic virus. In theory, other pancreatic cells capable of supporting virus infection might prolong the infection in islets and help beta cells to become infected.

Infections caused by EV-7 and 11 were vigorous in human islets and they resulted in rapid disturbances in beta-cell functions suggesting that they could be diabetogenic in vivo as well. The effects of EV-6 on beta cells from different donors was somewhat more variable. Recently we described an infant who developed immune-mediated Type I diabetes in utero already and according to our serological analysis the pathogenic process might have been induced by echovirus 6 infection during pregnancy [20]. Another echovirus, EV-9 DM, was recently isolated from a 6-week-old girl with an acute onset of Type I diabetes [21] and according to our present results, high multiplicity infection by this isolate results in impaired beta-cell function. The isolate was clearly more destructive than the corresponding prototype strains Barty or Hill. In contrast to these results, the same stool isolate has been tested in islets without further passaging in BGM cells, and was found to be incapable of growing or causing beta-cell death in cultured human islets, infected at a multiplicity of 1 [21]. This contradiction is not yet solved. In addition to donor-related variation in islets, virus passage history and multiplicity of infection might have contributed to the different results. Furthermore, the results probably also vary due to variable viability of islet cells depending on the ischaemia time and other technical factors in islet isolation.

Throughout our studies serum free culture medium was used in order to ensure most efficient infection of islets. In some other studies serum containing culture medium has been used for human islet infections and this could explain the differences between their results [25] and those previously published by us [22].

The prototype strain of echovirus 30 was one of the viruses causing no beta-cell damage in our study. Unlike PVs and CBVs, this serotype has existed in Europe and Northern America as a single genotype 
A
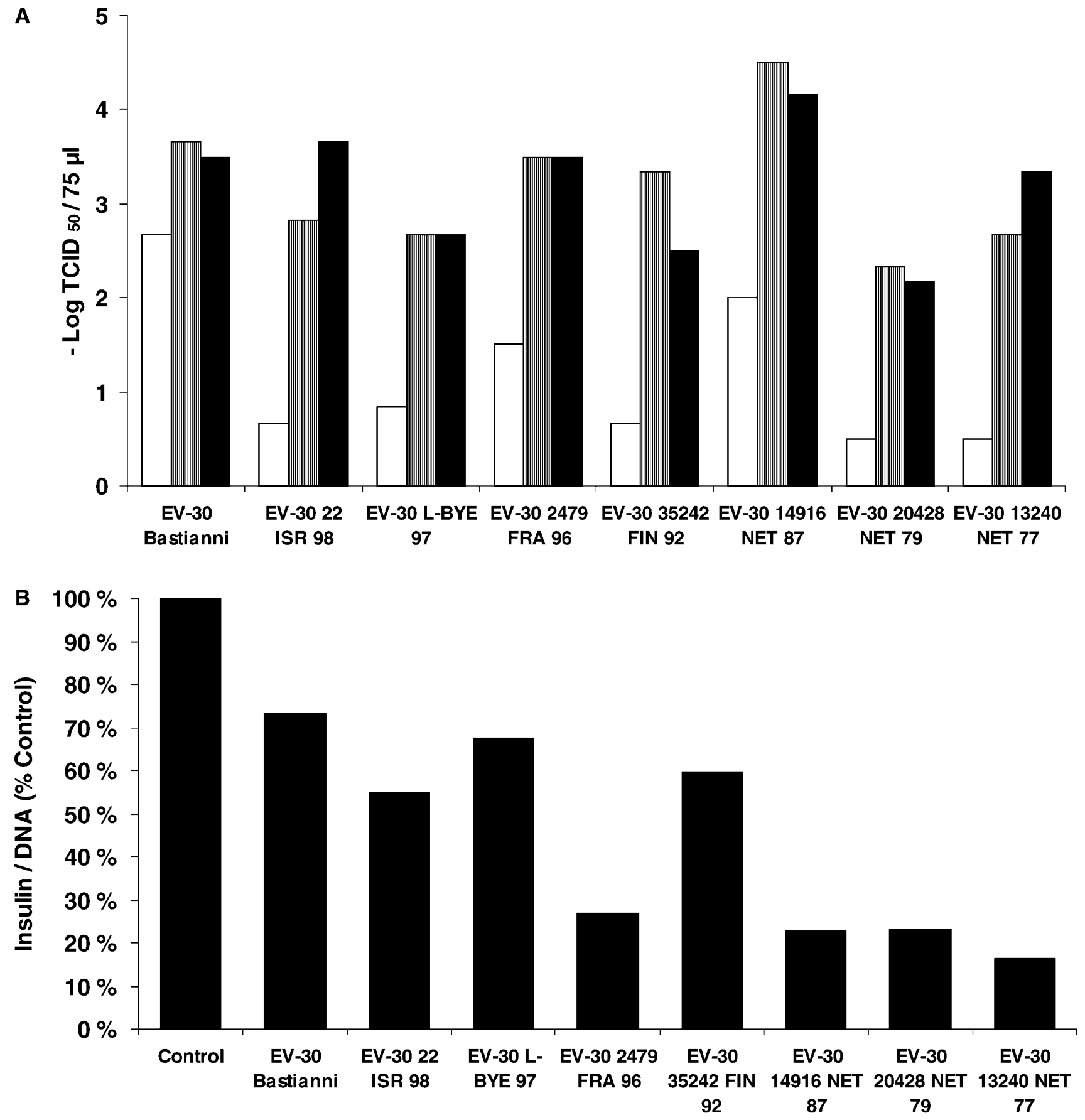

Fig. 6A, B. Beta cell destruction caused by field isolates of EV-30. A Replication of different isolates (left column, $0 \mathrm{~h}$; middle column, 1 day; right column, 2 days). B Effect of virus infection on beta-cell-specific destruction is shown by intracellular insulin content

since 1980s, and a specific subgenotypic lineage has shown a pandemic spread during 1990s [26]. In studies where beta-cell tropism of representatives of three subgenotypes was analysed we found clear differences in their diabetogenic properties. Strains isolated in 1977, 1979, 1987, and 1996 were clearly more destructive than the others. In phylogenetic analysis [26] these strains did not cluster together. The limited sequence data available did not reveal any specific patterns related to the capacity to cause beta-cell damage (not shown, [26]). Altogether, our present results from the field isolates strongly suggest that highly diabetogenic variants exist even among echovirus serotypes whose prototype strains appear not to cause beta-cell damage. Strain-specific variation of diabetogenicity is as such, not surprising. While within-serotype variation of enterovirus genomes can be extensive, several examples exist where individual point mutations could dramatically affect the virulence of a virus both in humans [32] and in animal models [33]. The experimental in vitro system presented in this paper would allow 
investigations on the genetic beta cell virulence but this would first require construction of infectious cDNA clones of suitable pairs of virus strains.

In contrast to $\mathrm{CBV}$-like viruses, some viruses increased rather than decreased the insulin responses to secretagogues. This was especially true for CAV-9 and both strains of EV-9 at one week after infection. However, in four out of seven experiments where insulin responses of CAV-9-infected islets were followed for several weeks, an impairment in the responses (at least one response was less than $40 \%$ of controls) was seen after two or three weeks of infection (not shown). Interestingly, in the cases of CBV-1 and CBV-4-E2 insulin responses to glucose (first or second phase) were practically unchanged while insulin response to glucose and theophylline were already significantly impaired. This is probably due to variation of beta-cell destruction kinetics induced by different viruses. This kind of enhanced insulin release was a phenomenon regularly found to precede the final destruction of porcine fetal beta cells after coxsackievirus infections [34].

In conclusion, we have shown that several prototype strains of enteroviruses including coxsackieviruses of subgroups A and B, poliovirus type 1/Mahoney, echoviruses and HPEV-1 infect, cause functional damage, and kill primary adult human beta cells. Remarkably, even when prototype strains were not destructive, highly destructive strains could be found among field isolates of the serotype. It is, of course, possible that islets cultured in vitro show susceptibility patterns different from those in vivo. However, it is important to note that instead of dissociated beta cells, we used cultures of intact islets including, in addition to beta cells, the glucagon-producing alpha cells, the somatostatin-producing delta cells, the PP-producing cells, and a number of islet-associated ductal epithelial cells. Furthermore, we have especially focussed on the effects of enterovirus infections on beta-cell function, measured by stimulated insulin release. There is no way to study this in humans in vivo. The best knowledge on diabetogenic properties of enteroviruses can be obtained only by combining results from different kinds of studies, including serological- and epidemiological-, clinical, animal and in vitro beta-cell studies.

Our results suggest that all enterovirus serotypes could be considered as potentially diabetogenic in genetically susceptible individuals. Furthermore, these results strengthen the notion that direct infection of the beta cells might also take place in vivo, and although this is likely to be the direct cause of diabetes in only rare cases, it could more often be a triggering event for beta-cell-targeted autoimmunity. Improved understanding of these pathogenic processes is of utmost importance for future preventive strategies.

Acknowledgements. The authors wish to thank Professor J.-W. Yoon for the diabetogenic E2 strain of CBV-4 used in the study, Ms M. Eskelinen for skilful technical assistance, and the personnel of the beta-cell Transplant Laboratory, Brussels, Belgium for the preparation of human islet cells. This study was supported by grants from the Academy of Finland, the Sigrid Juselius Foundation, Finnish Diabetes Research Foundation, The Juvenile Diabetes Research Foundation, the Research Fund of the Helsinki University Central Hospital and the European Community (contract No. BMH4-CT98-3952).

\section{References}

1. Yoon JW, Austin M, Onodera T, Notkins AL (1979) Isolation of a virus from the pancreas of a child with diabetic ketoacidosis. N Engl J Med 300: 1173-1179

2. Yoon JW (1990) The role of viruses and environmental factors in the induction of diabetes. Curr Topics Microbiol Immunol 164: 95-123

3. King ML, Shaikh A, Bidwell D, Voller A, Banatvala JE (1983) Coxsackie-B-virus-specific IgM responses in children with insulin-dependent (juvenile-onset; type I) diabetes mellitus. Lancet i: 1397-1399

4. Banatvala JE, Bryant J, Schernthaner G et al. (1985) Coxsackie B, mumps, rubella, and cytomegalovirus specific IgM responses in patients with juvenile-onset insulin-dependent diabetes mellitus in Britain, Austria, and Australia. Lancet i: $1409-1412$

5. Frisk G, Nilsson E, Tuvemo T, Friman G, Diderholm H (1992) The possible role of Coxsackie A and echo viruses in the pathogenesis of type I diabetes mellitus studied by IgM analysis. J Infect 24: 13-22

6. Helfand RF, Gary HE Jr, Freeman CY, Anderson LJ, Pallansch MA (1995) Serologic evidence of an association between enteroviruses and the onset of type 1 diabetes mellitus. Pittsburgh Diabetes Research Group. J Infect Dis 172: 1206-1211

7. Dahlquist GG, Ivarsson S, Lindberg B, Forsgren M (1995) Maternal enteroviral infection during pregnancy as a risk factor for childhood IDDM. A population-based casecontrol study. Diabetes 44: 408-413

8. Hyoty H, Hiltunen M, Knip M et al. (1995) A prospective study of the role of Coxsackie B and other enterovirus infections in the pathogenesis of IDDM. Diabetes 44: 652657

9. Hiltunen M, Hyoty H, Knip M et al. (1997) Islet cell antibody seroconversion in children is temporally associated with enterovirus infections. Childhood Diabetes in Finland (DiMe) Study Group. J Infect Dis 175: 554-560

10. Chehadeh W, Weill J, Vantyghem MC et al. (2000) Increased level of interferon-alpha in blood of patients with insulin-dependent diabetes mellitus: relationship with coxsackievirus B infection. J Infect Dis 181: 1929-1939

11. Gerling I, Chatterjee NK (1990) Autoantigen (64000-Mr) expression in coxsackievirus B4-induced experimental diabetes. Curr Topics Microbiol Immunol 156: 55-62

12. See DM, Tilles JG (1995) Pathogenesis of virus-induced diabetes in mice. J Infect Dis 171: 1131-1138

13. Kaufman DL, Erlander MG, Clare-Salzler M, Atkinson MA, Maclaren NK, Tobin AJ (1992) Autoimmunity to two forms of glutamate decarboxylase in insulin-dependent diabetes mellitus. J Clin Invest 89: 283-292

14. Lonnrot M, Hyoty H, Knip M et al. (1996) Antibody crossreactivity induced by the homologous regions in glutamic acid decarboxylase (GAD65) and 2C protein of coxsackievirus B4. Childhood Diabetes in Finland Study Group. Clin Exp Immunol 104: 398-405

15. Harkonen T, Puolakkainen M, Sarvas M, Airaksinen U, Hovi T, Roivainen M (2000) Picornavirus proteins share 
antigenic determinants with heat shock proteins 60/65. J Med Virol 62: 383-391

16. Vreugdenhil GR, Geluk A, Ottenhoff THM, Melchers WJG, Roep BP, Galama JMD (1998) Molecular mimicry in diabetes mellitus: The homologous domain in coxsackie B virus protein. Diabetologia 41: 40-46

17. Roivainen M, Knip M, Hyoty H et al. (1998) Several different enterovirus serotypes can be associated with prediabetic autoimmune episodes and onset of overt IDDM. Childhood Diabetes in Finland (DiMe) Study Group. J Med Virol 56: 74-78

18. Wagenknecht LE, Roseman JM, Herman WH (1991) Increased incidence of insulin-dependent diabetes mellitus following an epidemic of Coxsackievirus B5. Am J Epidemiol 133: 1024-1031

19. Rewers M, LaPorte RE, Walczak M, Dmochowski K, Bogaczynska E (1987) Apparent epidemic of insulindependent diabetes mellitus in Midwestern Poland. Diabetes 36: 106-113

20. Otonkoski T, Roivainen M, Vaarala O et al. (2000) Neonatal Type I diabetes associated with maternal echovirus 6 infection: a case report. Diabetologia 43: 1235-1238

21. Vreugdenhil GR, Schloot NC, Hoorens A et al. (2000) Acute onset of type I diabetes mellitus after severe echovirus 9 infection: putative pathogenic pathways. Clin Infect Dis 31: 1025-1031

22. Roivainen M, Rasilainen S, Ylipaasto P et al. (2000) Mechanisms of coxsackievirus-induced damage to human pancreatic beta-cells. J Clin Endocrinol Metab 85: 432-440

23. Yoon JW, Onodera T, Notkins AL (1978) Virus induced diabetes mellitus part 15 beta cell damage and insulin dependent hyper glycemia in mice infected with coxsackievirus B-4. Exp Med148: 1068-1080

24. Frisk G, Diderholm H (2000) Tissue culture of isolated human pancreatic islets infected with different strains of coxsackievirus B4: assessment of virus replication and effects on islet morphology and insulin release. Int J Exp Diabetes Res 1: 165-175
25. Chehadeh W, Kerr-Conte J, Pattou F et al. (2000) Persistent infection of human pancreatic islets by coxsackievirus $\mathrm{B}$ is associated with alpha interferon synthesis in beta cells. J Virol 74: 10153-10164

26. Savolainen C, Hovi T, Mulders MN (2001) Molecular epidemiology of echovirus 30 in Europe: succession of dominant sublineages within a single major genotype. Arch Virol 146: 521-537

27. Hovi T, Roivainen M (1993) Peptide antisera targeted to a conserved sequence in poliovirus capsid VP1 cross-react widely with members of the genus Enterovirus. J Clin Microbiol 31: 1083-1087

28. Hinegardner RT (1971) An improved fluorometric assay for DNA. Anal Biochem 39: 197-201

29. Otonkoski T, Beattie GM, Mally MI, Ricordi C, Hayek A (1993) Nicotinamide is a potent inducer of endocrine differentiation in cultured human fetal pancreatic cells. J Clin Invest 92: 1459-1466

30. Otonkoski T, Hayek A (1995) Constitution of a biphasic insulin response to glucose in human fetal pancreatic betacells with glucagon-like peptide 1. J Clin Endocrinol Metab 80: 3779-3783

31. Nelsen-Salz B, Eggers HJ, Zimmermann H (1999) Integrin alpha(v)beta3 (vitronectin receptor) is a candidate receptor for the virulent echovirus 9 strain Barty. J Gen Virol 80: 2311-2313

32. Macadam AJ, Stone DM, Almond JW, Minor PD (1994) The $5^{\prime}$ noncoding region and virulence of poliovirus vaccine strains. Trends Microbiol 2: 449-454

33. Knowlton KU, Jeon ES, Berkley N, Wessely R, Huber S (1996) A mutation in the puff region of VP2 attenuates the myocarditic phenotype of an infectious cDNA of the Woodruff variant of coxsackievirus B3. J Virol 70: 78117818

34. Roivainen M, Ylipaasto P, Ustinov J, Hovi T, Otonkoski T (2001) Screening enteroviruses for beta-cell tropism using foetal porcine beta-cells. J Gen Virol 82: 1909-1916 